\title{
ÉTICA NAS PUBLICAÇÕES CIENTÍFICAS
}

A ética é um termo genérico que engloba diversas reflexões sobre as relações entre os seres humanos e seu modo de ser e de pensar. Ela está disseminada em todas as atividades onde exista o confronto entre o bem e o mal, ou melhor, ações positivas ou negativas. A ética deve reger todos os campos de atividades humanas, e por isso tem diversas variações, como ética na ciência, política, economia, negócios, química, medicina e publicações científicas. Atualmente um dos termos mais comentados é a bioética, que é uma ética aplicada nas áreas das Ciências da Vida e da Saúde. Ética se diferencia da moral em muitos aspectos, pois ela é regra permanente universal, enquanto a moral é conduta temporária.

Não é nossa intenção fazer uma digressão sobre a ética, pois este tema e suas diversas variações são muito bem exploradas em livros e artigos publicados. Como Química Nova é um periódico bastante procurado pela comunidade científica, nesta reflexão, pretendemos levar aos nossos leitores, revisores e autores algumas questões de grande relevância relacionadas com a ética nas publicações científicas.

Este tema não é inédito, e muitos editores de jornais científicos têm sido confrontados com situações que envolvem a ética. ${ }^{1-3}$ Rodrigues e colaboradores, ${ }^{2}$ por exemplo, destacam o mal que a fraude pode causar "....algumas irregularidades que a ética condena, tais como: fraude; desonestidade; apresentação prematura de resultados; mentira; omissão; adulteração; violação; e deturpação, encontrados em artigos de resultados duvidosos, falsos ou distorcidos, alterando rumos de pesquisas de outros e comprometendo experimentos, leviana e irresponsavelmente". Como são muitas as questões que envolvem este tema, alguns periódicos criaram suas próprias regras éticas (ethical guidelines). Porém, estas regras não impediram episódios recentes de fraudes, que dependem da consciência e idoneidade dos seres humanos.

A questão da colaboração e co-autoria deve ser muito bem resolvida entre os autores antes da submissão do artigo. Todos os autores devem assinar um documento concordando com a publicação e o autor principal deve ter em seus arquivos este documento.

Nenhum co-autor que tenha tido pouca ou nenhuma participação deve entrar na publicação. Os manuscritos a serem submetidos sobre dissertações e teses devem ser discutidos com o orientador, assim como qualquer dado que venha a ser incluído numa nova publicação. É muito desagradável, para a editoria de um jornal científico, receber reclamações dos tipos: "não sabia da existência deste trabalho"; "nunca fui consultado sobre este trabalho", etc. De forma similar, e também perniciosa, é a omissão de autores que tenham efetivamente compartilhado do trabalho.

Os agradecimentos não precisam se limitar aos financiadores. Devem incluir colaboradores que, de alguma forma, contribuíram para o trabalho. No entanto, aqueles que estão sendo agradecidos precisam concordar com a inclusão do seu nome, pois a forma do agradecimento pode, eventualmente, causar discordância.

A citação de um artigo científico é outro aspecto de grande relevância que tem sido utilizada para diversos fins. Portanto, a revisão de literatura para uma busca dos artigos publicados anteriormente é obrigatória e espera-se que os autores citem estes trabalhos, pois, se por um lado, a omissão de estudos anteriores compromete a qualidade do artigo, por outro lado, a citação textual sem a fonte, devidamente registrada, configurase como plágio.

Os trabalhos submetidos são de total responsabilidade dos autores. Eles devem ser oriundos de material de pesquisa inédito, ressalvando-se os artigos de revisão. Portanto, manipulação/fabricação/supressão de dados, duplicação de publicações (efeito salame), publicação de trabalhos sob contrato e sob contrato de confidencialidade, dados de empresas, material obtido de experimentos não éticos, publicações sem consentimento, omissão de autores, plágio, publicação de dados confidenciais são consideradas faltas éticas graves. Entretanto, centenas de casos têm sido relatados envolvendo falta de ética nas publicações científicas, como pode ser observado no endereço da Internet do "Committee on Publication Ethics" (http://www.publicationethics.org.uk/), o que demonstra o quão grave é este problema.

No editorial da Química Nova n ${ }^{\circ} 2$ de 2006, ${ }^{4}$ o editorialista destacou esta mensagem: "Nem sempre a rapidez em divulgar os resultados de uma pesquisa deve ser a nossa força motriz, pois o que deve sempre importar é a exatidão e a consistência do que publicamos".

Os Editores de Química Nova, preocupados com estas questões, ressaltam que as pressões para aumentar o nível de publicação individual, institucional ou de um país não podem servir de desculpa para a falta de ética numa publicação.

\section{Susana I. Córdoba de Torresi \\ Vera L. Pardini \\ Vitor F. Ferreira \\ Editores de QN}

\section{REFERÊNCIAS}

1. Pinto, A. C.; Editorial, J. Braz. Chem. Soc. 1999, 10, 2.

2. Rodrigues, A. V. F.; Crespo, I. M.; Miranda, C. L.; Em Questão 2006, 12, 33.

3. Muccioli, C.; Campos, M.; Goldchmit, M.; Dantas, P. E. C.; Bechara, S. J.; Costa, V. P.; Editorial, Arq. Bras. Oftalmol. 2006, 69, 787.

4. Coelho, F. S.; Editorial, Quim. Nova 2006, 29, 185. 